\title{
Serological Evidence of HTLV-I and HTLV-II Coinfections in HIV-1 Positive Patients in Belém, State of Pará, Brazil
}

\author{
ACR Vallinoto, VN Azevedo, DEM Santos, S Caniceiro, FCL Mesquita*, \\ WW Hall**, MOG Ishak, R Ishak/ ${ }^{+}$
}

\begin{abstract}
Universidade Federal do Pará, Centro de Ciências Biológicas, Caixa Postal 13005, 66040-970 Belém, PA, Brasil
\end{abstract}
*Hospital Universitário João de Barros Barreto, Belém, PA, Brasil **University College Dublin, Ireland

The occurrence of HTLV-I/II and HIV-1 coinfections have been shown to be frequent, probably in consequence of their similar modes of transmission. This paper presents the prevalence of coinfection of HTLV among HIV-1 infected and AIDS patients in Belém, State of Pará, Brazil. A group of 149 patients attending the AIDS Reference Unit of the State Department of Health was tested for the presence of antibodies to HTLV-I/II using an enzyme immunoassay and the positive reactions were confirmed with a Western blot that discriminates between HTLV-I and HTLV-II infections. Four patients (2.7\%) were positive to HTLV-I, seven (4.7\%) to HTLV-II and one (0.7\%) showed an indeterminate pattern of reaction. The present results show for the first time in Belém not only the occurrence of HTLV-II/HIV-1 coinfections but also a higher prevalence of HTLV-II in relation to HTLV-I. Furthermore, it also enlarges the geographical limits of the endemic area for HTLV-II in the Amazon region of Brazil.

Key words: HIV - HTLV - coinfection - retrovirus

The human immunodeficiency virus type 1 (HIV-1) is a worldwide distributed pathogen and the occurrence of coinfections with other human retroviruses like the human T-cell lymphotropic virus type I and II (HTLV-I and HTLV-II) has been shown to be a fairly common event in Brazil (Schechter et al. 1994, Brites et al. 1997). The similar modes of transmission of the same organic fluids in which HIV and HTLV are present, favours their joint transmission, sharing the same human host when the viruses occur in the same epidemiological setting (Galvão-Castro 1994).

In Brazil, HIV/HTLV coinfections are relatively high and are associated to some risk factors that include previous blood transfusion and intravenous drug usage. Prognosis of such coinfections is a controversial matter and it is suggested that in the course of disease patients can be significantly deprived (Schechter et al. 1994, Brites et al. 1997). This is a matter, however, that needs to be further clarified.

This paper presents the prevalence and risk factors involved in the coinfections of HTLV-I and HTLV-II, among HIV-1 infected and AIDS patients in Belém, State of Pará, Brazil.

\footnotetext{
The present work was partially supported by grants from the Universidade Federal do Pará and Conselho Nacional de Desenvolvimento Científico e Tecnológico-CNPq. +Corresponding author. Fax:+55-91-212.2468

Received 11 March 1998

Accepted 16 April 1998
}

\section{MATERIALS AND METHODS}

Population group examined - A group of 149 patients (124 males and 25 females, aged between 18 and 66 years of age; mean 31.7 years) attending the AIDS Reference Unit of the State Health Department in Belém during the period between August 1994 and September 1996, were included in the present study. The patients were routinely tested for HIV using an enzyme immunoassay and seroreactivity to HIV was confirmed by the use of an immunofluorescence assay. These tests were performed in the public health laboratory network of the Brazilian Ministry of Health. All the subjects were requested to sign an informed consent form, had a sample of blood collected and answered a questionnaire that aimed at collection of demographic data, present clinical status and presumed previous risk factors for HIV and HTLV infections, such as the use of intravenous drugs, history of blood transfusion and sexual preferences. Serum samples were kept at $-20^{\circ} \mathrm{C}$ before use.

Serological assays - All the patients had their HIV-1 infection confirmed through the State Health Department network for the serological diagnosis of HIV-1. Serum samples were further screened for the presence of antibodies to HTLV-I/II using an enzyme immunoassay (EIA, Murex, England). The positive reactions were further tested using a Western blot (Genelabs 2.4, USA) that permits confirmation and differentiation of HTLV-I and HTLV-II seroreactivity. The discriminatory criteria of the Western blot followed the manufacturer's 
recommendations of reactivity to $\mathrm{p} 19, \mathrm{p} 24$ and to the synthetic peptides added to the kit, that specifically react with HTLV-I (MTA-1, rgp46-I) and HTLV-II (K55, rgp46-II).

\section{RESULTS}

The prevalence of antibodies to HTLV in HIV1 infected patients was found to be 7.4\% (11/149). Evidence of HIV-1/HTLV-I coinfection was found in four subjects $(2.7 \%)$ and HIV-1/HTLV-II in seven subjects $(4.7 \%)$. A single symptomatic female AIDS patient showed an indeterminate pattern of reaction. A detailed description of the coinfected patients is listed in Table.

HIV-1/HTLV-I coinfection was present in four asymptomatic male homosexual or bisexual subjects. Among the HIV-1/HTLV-II positives there were three asymptomatic (homo or bisexual) and three symptomatic (homo or heterosexual) male patients, and one asymptomatic female.

Four patients referred the use of intravenous drugs (two HTLV-I and two HTLV-II positives) and only three confirmed to have had sex with drug users. Their sexual preferences were not related to the positivity to HTLV infection, but almost all of the subjects $(10 / 12)$ referred multiple number of sexual partners.

\section{DISCUSSION}

HIV-1/HTLV coinfection has been shown to be common in epidemiological settings where the prevalence of both viruses is high (Galvão-Castro 1994). The data presented here is a reflection of the descriptive epidemiology of the HIV and AIDS epidemics in Belém, where HIV and HTLV-I/II occur in a much lower prevalence than in the rest of the country (Boletim Epidemiológico/AIDS 1996).

Among the risk factors taken into consideration, the transmission of HTLV-I and HTLV-II among HIV-1 infected and AIDS patients, was closely associated to sexual contact with multiple partners. This data is clearly different from what has been previously reported by Brites et al. (1997) in Salvador, State of Bahia, relating such coinfections with previous blood transfusion and the use of intravenous drugs, similarly to transmission reported in other parts of the world (Lee et al. 1991). On the other hand, this is the first time that HTLV-II is detected in a higher frequency than HTLV-I in a Brazilian urban setting coinfecting HIV carriers and AIDS patients.

HTLV-II is largely disseminated in the Amazon region among several Indian communities (Ishak et al. 1995) and only very recently the presence of that virus (subtype HTLV-IIa) has been detected in an urban community of the region among blood donors in Belém (Ishak et al. 1998).

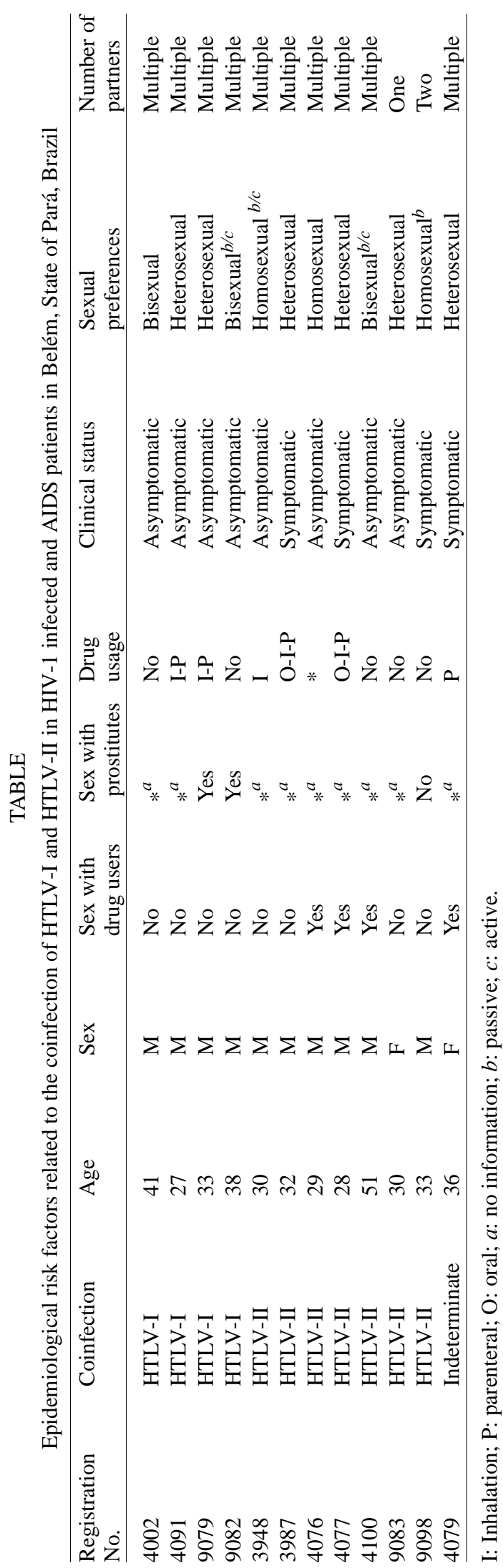


Sequencing of the LTR region of the genome revealed a virus that clusters together with other HTLV-IIa that are endemic in the region (data not published).

The critical question to be answered regards the outcome of the coinfection of HTLV among HIV-1 infected and AIDS patients. Particularly, HTLV-II is a virus that is still controversial as a cause of disease (Hall et al. 1996). The present information highlights the enlargement of the geographical limits of the endemic area of HTLV-II in the Amazon region and a prospective work is of paramount importance to compare the prognosis of its coinfection with HIV-1.

\section{ACKNOWLEDGMENTS}

To all the patients involved in the present study.

\section{REFERENCES}

Boletim Epidemiológico, Brasília: PN-DST/AIDS 1996. AIDS Semana Epidemiológica, p. 3-39, Ano IX No. 02.

Brites C, Harrington Jr W, Pedroso C, Netto EM, Badaró R 1997. Epidemiological characteristics of HTLV-I and II coinfection in Brazilian subjects infected by HIV-1. Braz J Infec Dis 1: 42-47.

Galvão-Castro B 1994. Investigação laboratorial da infecção pelo HTLV-I/II e frequiência da co-infecção com o HIV. Rev Soc Bras Med Trop 27: 472-477.

Hall WW, Ishak R, Zhu SW, Novoa P, Eiraku N, Takahashi H, Costa-Ferreira M, Azevedo VN, Ishak MOG, Costa-Ferreira O, Monken C, Kurata T 1996. Human T lymphotropic virus type II (HTLV-II): epidemiology, molecular propeties and clinical features of infection. J Acq Imm Def Synd Hum Retrov 13 (Suppl. 1): S204-S214.

Ishak R, Harrington Jr WJ, Azevedo VN, Eiraku N, Ishak MOG, Guerreiro JF, Santos SEB, Kubo T, Monken C, Alexander S, Hall WW 1995. Identification of T cell lymphotropic virus type IIa in the Kayapo, an indigenous population of Brazil. AIDS Res Hum Retrov 11: 813-821.

Ishak R, Ishak MOG, Azevedo VN, Santos DEM, Vallinoto ACR, Saraiva JCP, Crescente JA, Hall WW 1998. Detection of HTLV-IIa in blood donors in an urban area of the Amazon Region of Brazil (Belém,Pará). Rev Soc Bras Med Trop 31: 193-197.

Lee HH, Swanson P, Rosenblatt J, Chen ISY, Sherwood WC, Smith D, Tegtmeier GE, Fernando LP, Fang CT, Osame M, Kleinman SH 1991. Relative prevalence and risk factors of HTLV-I and HTLV-II infection in US blood donors. Lancet 337: 1435-1439.

Schechter M, Harrinson LH, Halsey NA, Trade G, Santino M, Moulton LH, Quinn TC 1994. Coinfection with human T-cell lymphotropic virus type I and HIV in Brazil: Impact on markers of HIV diseases progression. JAMA 271: 353-357. 
HTLV-I/II Coinfections in HIV-1 Positive Patients - ACR Vallinoto et al. 